\title{
Relationships between sediments and tissue contamination and allozymic patterns in Hediste diversicolor (Polychaeta Nereididae) in the Pialassa lagoons (north Adriatic Sea)
}

\author{
Relations entre la contamination des tissus et des sédiments et \\ l'organisation des systèmes enzymatiques chez Hediste diversicolor \\ (Polychaeta Nereididae) dans les lagunes de Pialassa \\ (nord de l'Adriatique)
}

\author{
Massimiliano Virgilio *, Nicola Baroncini, Claudio Trombini, Marco Abbiati \\ Centro Interdipartimentale di Ricerca per le Scienze Ambientali in Ravenna, Università di Bologna, Via Tombesi dall'Ova 55, I-48100 Ravenna, Italy
}

Received 31 July 2002; accepted 30 September 2002

\begin{abstract}
An increasing number of investigations revealed that responses of populations to environmental stressors may be genetically dependent. Occurrence of genetic adaptation to high concentrations of heavy metals in Hediste diversicolor local ecotypes has also been hypothesised. Analyses of allozymic patterns are a promising tool for the genetic monitoring of environmental stressors. The aim of this study was to investigate whether the allozymic patterns of $H$. diversicolor could be affected by levels of contamination. Five sites were investigated: four in a polluted brackish habitat, the Pialassa lagoons, and a reference site in the Lamone estuary. Total mercury was used as a tracer of the overall level of contamination. Concentrations of mercury were quantified in both sediments and $H$. diversicolor tissues by means of cold vapour atomic fluorescence spectroscopy. A gradient of mercury concentration in both sediments and $\mathrm{H}$. diversicolor tissues was found. Moreover, significant differences in concentration of mercury were observed among and within sites. Allozyme electrophoresis was used to test the occurrence of genetic differentiation among $H$. diversicolor samples. A total of 19 putative gene loci were analysed. For six gene loci, significant variability in genotypic and allelic frequencies was detected. Patterns of differentiation, which could be related to the contamination levels, were found at loci LDH, PGI, SDH. Other loci (ALD, FH, HBDH) showed a significant genetic structuring among samples, not related to concentrations of mercury.
\end{abstract}

(C) 2003 Éditions scientifiques et médicales Elsevier SAS and Ifremer/CNRS/IRD. All rights reserved.

Résumé

Un nombre croissant de travaux montre que les réponses des populations à des perturbations de l'environnement dépendent du patrimoine génétique. La fréquence de l'adaptation génétique à des teneurs élevées de métaux lourds dans des écotypes locaux de l'espèce Hediste diversicolor a également été avancée. L'analyse de l'organisation des systèmes enzymatiques représente un outil prometteur pour le suivi génétique dans des conditions environnementales perturbées. L'objectif de cette étude est de rechercher si l'organisation des systèmes enzymatiques d' H. diversicolor pourrait être affectée par les concentrations en contaminants. Cinq sites ont été étudiés : quatre dans un habitat saumâtre pollué, les lagunes de Pialassa et un site de référence dans l'estuaire de la Lamone. Le mercure total est utilisé comme indicateur du niveau global de contamination. Les concentrations de mercure ont été mesurées dans le sédiment et dans les tissus du polychète grâce à la spectroscopie atomique de fluorescence en vapeur froide. Un gradient de concentrations de mercure a été trouvé aussi bien dans les sédiments que dans l'annélide. De plus, des différences significatives de concentrations de mercure ont été observées entre les sites et au sein même d'un site. L'électrophorèse des systèmes enzymatiques a été utilisée pour tester la fréquence de la différentiation génétique au sein des échantillons

* Corresponding author.

E-mail address: mvirgilio@ambra.unibo.it (M. Virgilio). 
d'H. diversicolor. Dix-neuf locus probables des gènes ont été analysés. Pour six d'entre eux, une variabilité significative dans la fréquence des allèles et dans la fréquence génotypique a été détectée. Les schémas de différentiation qui pourraient être reliés aux niveaux de contamination ont été trouvés aux locus LDH, PGI, SDH. D'autres locus (ALD, FH, HBDH) présentent une structuration génétique significative au sein des échantillons mais qui n'est pas liée aux concentrations de mercure.

(C) 2003 Éditions scientifiques et médicales Elsevier SAS et Ifremer/CNRS/IRD. Tous droits réservés.

Keywords: Hediste diversicolor; Contamination; Genetic structure; Adaptation; Allozyme

Mots clés : Hediste diversicolor ; Contamination ; Structure génétique ; Adaptation ; Systèmes enzymatiques

\section{Introduction}

Individuals, populations and species can differ widely in their tolerance to pollutants. The analysis of factors underlying tolerance is of basic importance in understanding adaptive mechanisms to different types of anthropogenic stressors (Woodward et al., 1996). Heavy metals are frequently found in polluted areas and have been widely studied (for a review on the topic see Klerks and Weis, 1987; Bryan and Langston, 1992). Tolerance to heavy metals can be defined as the ability to prevent, reduce or repair damage (Troncoso et al., 2000). Tolerance can be developed by means of physiological processes during individual exposure (acclimation), by selective processes on genetic variability (adaptation), or by a combination of both (Klerks and Weis, 1987). Heritability experiments showed genetic adaptation to cadmium, nickel and cobalt in populations of the benthic oligochaete Limnodrilus hoffmeisteri (Klerks and Levinton, 1989). Authors hypothesised the occurrence in L. hoffmeisteri of a rapid adaptation, since tolerance evolved in about 30 years from the beginning of the discharge in the study area. Klerks and Levinton (1989) supposed that the responses to directional selection in natural populations could be rapid and strong enough to maintain resistance differences despite gene flow.

Allozyme polymorphism can have measurable effects on physiological performance and, ultimately, on adaptation. Such physiological variability can be reflected in a trade-off between individual growth, fecundities, timing of reproduction, behaviour, or other critical aspects of life history (Mulvey et al., 1995). Differences in response to a stressor are supposed to be strongly genotype dependent, if involved loci play a major role in the flux of metabolites. Pollution has been described as a putative selective force influencing the pathway output and fitness related attributes of organisms (Benton and Guttman, 1997). An increasing number of investigations, based on allozymes, related the genetic structure of populations to the occurrence of environmental stressors (reviewed in Hummel and Patarnello, 1994). Shifts in allele frequencies in populations have been supposed to be related to the differential mortality of sensitive genotypes (Nevo et al., 1986). Some of these studies showed that electrophoretically defined genotypes can sensibly vary their frequencies in natural populations impacted by anthropogenic pollutants (e.g. Gillespie and Guttman, 1989; Patarnello et al., 1991; Roark and Brown, 1996). Moreover, differential survival of specific genotypes under acute laboratory exposure to heavy metals has been demonstrated (Nevo et al., 1984, 1987). These results suggest that analyses of genetic patterns could be a promising tool for the genetic monitoring of environmental stressors (Nevo et al., 1987; Patarnello et al., 1991; Roark and Brown, 1996; Woodward et al., 1996; Troncoso et al., 2000). Benthic invertebrates are particularly suited for this type of investigation because their habitat is often the depository for agricultural and industrial wastes (Benton and Guttman, 1992). Hediste diversicolor (Müller, 1776) is a typical inhabitant of European brackish water habitats, and it shows high levels of tolerance towards different types and concentrations of contaminants (Muhaya et al., 1997; SaizSalinas and Francés-Zubillaga, 1997; Volpi et al., 1999). Toxicological studies showed that $H$. diversicolor could develop local ecotypes tolerant to high concentrations of heavy metals and that tolerance was neither readily gained nor readily lost (Bryan and Hummerstone, 1971, 1973). The hypothesis of a genetic control of tolerance was supported by laboratory experiments demonstrating that tolerance to copper and zinc had a heritable component (Grant et al., 1989).

The aims of the present study were: to quantify patterns of genetic structure in $H$. diversicolor exposed to different levels of sediment pollution in the Pialassa lagoons; to assess if variation of genotypic and allelic frequencies could be related to levels of habitat contamination.

\section{Materials and methods}

\subsection{Study area}

The Pialassa lagoons are located along the northern Adriatic Italian coast $\left(44.4673-44.5293^{\circ} \mathrm{N}, \quad 012.2375\right.$ $-012.2705^{\circ} \mathrm{E}$, European Datum, 1950), between the city of Ravenna and the Lamone river estuary. Artificial embankments divide the lagoons in several shallow water ponds connected by channels. The inner channels are connected to the sea through the shipway Candiano channel. The average depth varies from $0.5 \mathrm{~m}$ in the shallow areas to $3 \mathrm{~m}$ in the channels with a tidal range variable from 0.3 to $1 \mathrm{~m}$, excluding extreme events (Ponti et al., in press). Tides cause large variations in the water levels and vast muddy areas emerge during low tides. Starting from the 1950s a massive industrialisation of the area transformed the southern coast of Pialassa Baiona into one of the major chemical districts of Italy. 


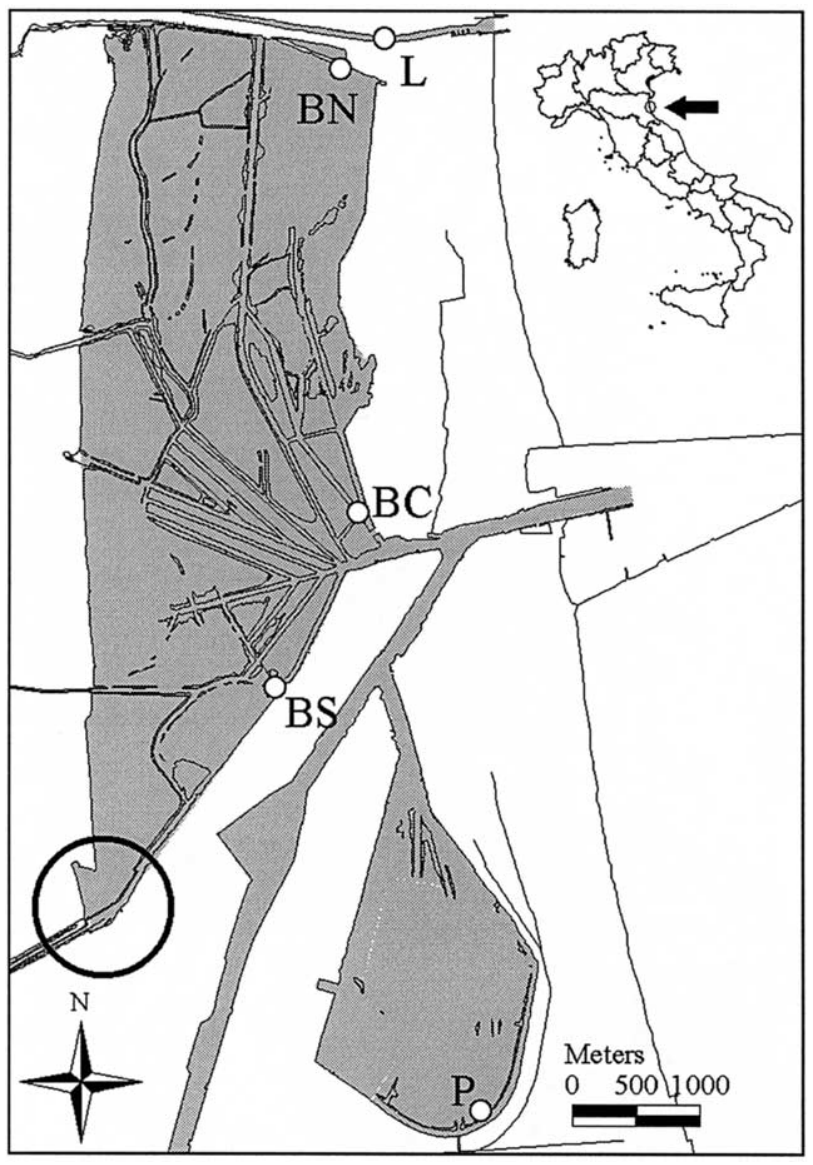

Fig. 1. Map of the study area. Sites are identified as follows: BS, Baiona south; BC, Baiona centre; BN, Baiona north; P, Piomboni and L, Lamone. The black circle identifies the area affected by the input of contaminants form the chemical district.

Until 1973, due to the lack of specific regulations, industrial wastes were released directly in the Pialassa Baiona lagoon without any treatment (Fabbri et al., 1998). At present pollution inputs are drastically reduced even if the basins still receive wastewater from urban and industrial treatment plants and from drainage channels of a large agricultural area (Ponti et al., in press). Four sites, Baiona south, Baiona centre, Piomboni and Baiona north, up to $9 \mathrm{~km}$ apart, were sampled at increasing distances from the main sources of industrial pollution. Outside the lagoons a reference site was located in the Lamone estuary Fig. 1. Sampling was carried out from May to July 2001.

\subsection{Analyses of mercury concentrations}

Previous studies on the Pialassa Baiona showed a correlation between total mercury concentrations in sediments and the overall level of contamination due to other pollutants, such as PAHs and synthetic polymers (Fabbri et al., 2000; Fabbri et al., 2001a). These results were ascribed both to the common history of the inputs and to the transport processes of pollutants across the Pialassa lagoons. Based on these studies, total mercury was used as a tracer of the overall level of pollution of sediments of the Pialassa lagoons.
At each site three samples of superficial sediments were collected in intertidal areas of about $25 \mathrm{~m}^{2}$ using a small corer to obtain approximately $20 \mathrm{~cm}$ deep cores. Three $\mathrm{H}$. diversicolor samples, represented by five individuals each, were collected at each site. Before analyses $H$. diversicolor specimens were kept for $72 \mathrm{~h}$ in glass dishes containing brackish water from the sampling sites to void the gut of sediment (Muhaya et al., 1997). The analyses of sediments and $H$. diversicolor tissues were performed in triplicate. Reagent blanks and certified reference materials, IAEA 356 (marine sediment) and SRM 2976 (mussel tissue), were analysed concurrently with sediment and tissue samples to validate the method used (precision 10\% and accuracy $92 \%$, as recovery with respect to the certified value). Sediment samples were mineralised with $\mathrm{H}_{2} \mathrm{SO}_{4} / \mathrm{K}_{2} \mathrm{Cr}_{2} \mathrm{O}_{7}$ at $140{ }^{\circ} \mathrm{C}$ for $2 \mathrm{~h}$ and immediately analysed for total mercury by cold vapour atomic fluorescence spectrometry (CVAFS), using a Tekran 2500 detector, according to Fabbri et al. (2001b). $H$. diversicolor tissues were digested with $\mathrm{HNO}_{3} / \mathrm{H}_{2} \mathrm{SO}_{4}$ and total mercury was analysed by CVAFS, according to Cattani et al. (1999). Differences in concentration values among samples and sites were tested by means of a two-way ANOVA, with site (five levels) as random factor and sample (three levels) as random factor nested in site. After Cochran's $C$-test, logarithmic transformation was used to homogenise variances of $H$. diversicolor tissues concentrations. SNK test was used for a posteriori multiple comparisons of means to identify possible spatial trends in mercury concentrations.

A qualitative estimate of the different fractions of mercury in the study area was carried out at the Baiona south site (core 3 ) and at the Baiona centre site (core 1). Sequential extraction designed as a modification of a protocol by Wallschlager et al. (1998) was applied. Three sequential steps were performed: in each step about $2 \mathrm{~g}$ of the solid sample were treated with $20 \mathrm{ml}$ of the extraction solution, under a nitrogen atmosphere. After centrifugation, the solid residue was used in the next step and the leachate was analysed for total mercury. The following fractions were operationally defined: mobile mercury as the mercury fraction extracted by stirring wet sediment with $4 \mathrm{M} \mathrm{HNO}_{3}$ at $0{ }^{\circ} \mathrm{C}$ for $1 \mathrm{~h}$; it should include elemental mercury, labile and carbonate associated mercury; humic acid-complexed mercury as the mercury fraction extracted by stirring the previous residue with $1 \mathrm{M}$ $\mathrm{KOH}$ at $20{ }^{\circ} \mathrm{C}$ for $24 \mathrm{~h}$; sulphide-bound mercury as the mercury fraction extracted by stirring the residue of the previous extraction at $20{ }^{\circ} \mathrm{C}$ for $24 \mathrm{~h}$ with a $\mathrm{Na}_{2} \mathrm{~S}$ solution obtained by dissolving $40 \mathrm{~g}$ of $\mathrm{Na}_{2} \mathrm{~S} \cdot 9 \mathrm{H}_{2} \mathrm{O}$ in $110 \mathrm{~g}$ of $1 \mathrm{M}$ $\mathrm{KOH}$. The analyses of mercury fractions were performed in triplicate. Differences in concentrations of mercury fractions in the two cores were tested using contingency $\chi^{2}$-test.

\subsection{Analyses of allozymic patterns}

At each of the five sites, the genetic structure of samples of $H$. diversicolor $(76<n<99)$ was analysed by cellulose acetate allozyme electrophoresis. Allelic frequencies at 15 enzymatic systems, corresponding to 19 putative gene loci 
were quantified. Analysed loci were aldolase (ALD, E.C. 4.1.2.13); aldehyde oxidase (AO1, AO2, E.C. 1.2.3.1); formaldehyde dehydrogenase (FDH, E.C. 1.2.1.1); fumarate hydratase (FH, E.C. 4.2.1.2); fructokinase (FK, E.C. 2.7.1.4); glycerol-3-phospate dehydrogenase (GPD1, GPD2, E.C. 1.1.1.8); 3-hydroxybutyrate dehydrogenase (HBDH, E.C. 1.1.1.30); isocitrate dehydrogenase (IDH1, IDH2, E.C. 1.1.1.42); lactate dehydrogenase (LDH, E.C. 1.1.1.27); malate dehydrogenase (MDH, E.C. 1.1.1.37); malic enzyme (ME1, ME2, E.C. 1.1.1.40); mannose-6-phosphate isomerase (MPI, E.C. 5.3.1.8); glucose-6-phosphate isomerase (PGI, E.C. 5.3.1.9); phosphoglucomutase (PGM, E.C. 2.7.5.1); sorbitol dehydrogenase (SDH, E.C. 1.1.1.14). About $100 \mathrm{mg}$ of tissues of $\mathrm{H}$. diversicolor were homogenised with $100 \mu \mathrm{l}$ of extracting buffer (Tris- $\mathrm{HCl} 0.05 \mathrm{M} \mathrm{pH} 8$, Triton X-100 1:1000), subjected to electrophoresis and stained following the procedures reported in Abbiati and Maltagliati (1996) and Pasteur et al. (1988) with slight modifications. TEM pH 7.8 electrode buffer (Schneppenheim and Mac Donald, 1984) was used. Multiple loci for a given enzyme were numbered from the less anodal locus. For each locus the most common allele observed in the sample from the Lamone site was designated as the 100 allele. Alternate alleles were assigned a value relative to the position of the 100 allele and their migration distance. Electrophoretic data, including allele and genotype frequencies, mean heterozygosity, percentage of polymorphic loci, goodness-of-fit of the data to expected Hardy-Weinberg equilibrium proportions, heterozygote deficiency or excess $\left(D=H_{\text {obs }}-H_{\text {exp }} / H_{\text {exp }}\right)$ and Nei's (1978) genetic distances were calculated using the Biosys computer software (Swofford and Selander, 1981). Differences in allelic and genotypic frequencies among samples were tested for significance by means of contingency $\chi^{2}$-tests performed both on the four Pialassa lagoons samples and on the overall Pialassa lagoons and Lamone estuary samples. When necessary, genotype classes were pooled to avoid errors from low expected numbers. The sequential Bonferroni correction was performed to control for type I errors.

\section{Results}

\subsection{Levels of mercury concentrations}

Total mercury concentrations measured in sediments Fig. 2 ranged from 15.7 to $13855.1 \mathrm{ng} \mathrm{g}^{-1} \mathrm{dw}$. Highly significant differences in concentrations among different sites were observed $\left(F_{4,10}=11.5 ; P<0.001\right)$ and a posteriori comparisons (SNK test) showed significantly higher values in the site Baiona south $(\mathrm{BS}>\mathrm{BC}=\mathrm{BN}=\mathrm{L}=\mathrm{P}$ ), with mean levels of mercury concentrations more than an order of magnitude higher $\left(\right.$ mean $[\mathrm{Hg}]=11391.6 \mathrm{ng} \mathrm{g}^{-1} \mathrm{dw}$, S.E. $\left.=447.5\right)$. Highly significant small scale variability was detected within sites among cores only a few metres apart $\left(F_{10,30}=865.8\right.$; $P<0.0001)$. Mercury fractions were not significantly different $\left(\chi^{2}=5.80\right.$, d.f. $\left.=2, P>0.05\right)$ between cores from sites

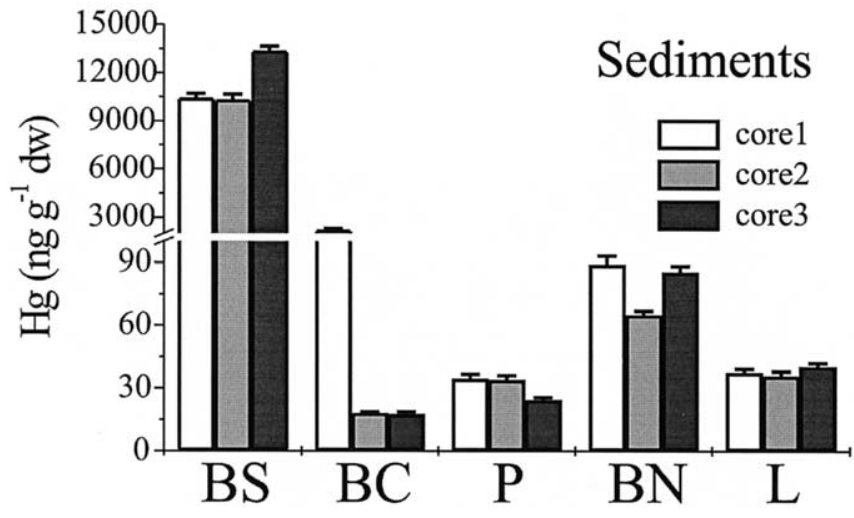

Fig. 2. Mean concentration of mercury (+ S.E., $n=3)$ in sediments at the five study sites. Sites abbreviation as in Fig. 1.

Baiona south (mobile mercury $=72.4 \%$, S.E. $=2.7$; humic acid-complexed mercury $=21.0 \%$, S.E. $=1.9$; sulphidebound mercury $=6.6 \%$, S.E. $=0.2$ ) and Baiona centre (mobile mercury $=56.7 \%$, S.E. $=4.7$; humic acid-complexed mercury $=29.8 \%$, S.E. $=5.1$; sulphide-bound mercury $=$ $13.5 \%$, S.E. = 0.4). Mercury concentrations in H. diversicolor tissues ranged from 22.8 to $466.2 \mathrm{ng} \mathrm{g}^{-1} \mathrm{dw}$. Significant differences among sites were revealed by ANOVA $\left(F_{4,10}=\right.$ 17.2; $P<0.001$ ). A posteriori comparisons (SNK test: BC > $\mathrm{BS}>\mathrm{P}=\mathrm{L}=\mathrm{BN}$ ) showed significantly higher concentrations of mercury at sites Baiona south (mean $[\mathrm{Hg}]=267.2 \mathrm{ng} \mathrm{g}^{-1}$ $\mathrm{dw}$, S.E. $=16.3)$ and Baiona centre $\left(\right.$ mean $[\mathrm{Hg}]=391.0 \mathrm{ng} \mathrm{g}^{-1}$ dw, S.E. $=18.5$ ). Highly significant small scale variability among samples of $H$. diversicolor within sites was also observed $\left(F_{10,30}=22.7 ; P<0.0001\right)$. Levels of mercury concentrations in sediments at the Lamone site were below the effects range low (ERL) for mercury in brackish habitats according to Long et al. (1995). Similar values were observed at sites Baiona north and Piomboni Fig. 2.

\subsection{Allozymic patterns of $H$. diversicolor}

Levels of genetic variation within samples of $H$. diversicolor from the Pialassa lagoons and Lamone estuary were rather low. The mean number of alleles per locus ranged from 0.025 , S.E. $=0.012$ at Baiona South to 1.84 , S.E. $=0.16$ at Lamone. Loci AO2, FDH, MDH, ME2 were monomorphic in all samples. Seven of the 19 putative gene loci (ALD, AO1, FH, HBDH, LDH, PGI, SDH) were polymorphic ( 0.95 criterion) in at least one sample. The percentage of polymorphic loci ( 0.95 criterion) ranged from 0.11 at Baiona south to 0.26 at Lamone. Levels of observed mean heterozygosity per locus ranged from $0.025($ S.E. $=0.012)$ at Baiona south to 0.052 (S.E. $=0.018$ ) at Lamone. In some samples private alleles occurred at low frequencies. No genetic differentiation among samples was recorded by Nei's genetic distance index (range: 0.000-0.003).

Evidences of genetic structuring among samples resulted from the distribution of the allelic and genotypic frequencies at six loci: ALD, FH, HBDH, LDH, PGI, SDH. 


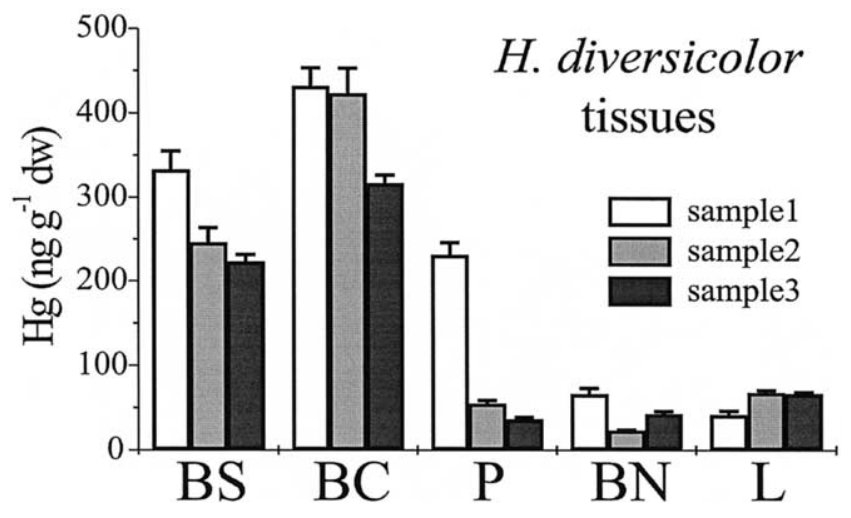

Fig. 3. Mean concentration of mercury (+ S.E., $n=3)$ in $H$. diversicolor tissues at the five study sites. Sites abbreviation as in Fig. 1.

For the ALD locus, contingency $\chi^{2}$ analyses performed on the four samples collected in the Pialassa lagoons revealed significant differences in allelic and pooled genotypic frequencies (Table 1). For this locus Piomboni sample had a higher proportion of 102 allele and 100/102 genotype Fig. 4. For FH locus, allelic frequencies differed significantly when all five samples were analysed together, but not when the comparison was made among samples of the Pialassa lagoons. A similar pattern was observed for genotype analyses Table 1. This pattern could be explained by the higher proportion of 102 allele and 100/102 genotype in the Lamone estuary sample Fig. 4. For the HBDH locus, differences in allelic frequencies were observed among samples of the Pialassa lagoons, with greater abundances of rare alleles in the Baiona north and Baiona centre samples Fig. 4. Pooled genotypic frequencies resulted significantly different among the overall Pialassa and Lamone samples, but analysis of the four Pialassa samples did not show significant variability Table 1. Locus LDH showed significant variability in allelic and pooled genotypic frequencies Table 1 among the four Pialassa samples. At this locus the Baiona south sample was characterised by a greater abundance of 100 allele and 100/100 genotype. The Baiona north and Baiona centre samples showed higher proportions of 98 allele and 98/100 genotype Fig. 5. A significant departure from Hardy-Weinberg equilibrium Table 2, due to heterozygote deficiency, was observed both in the Baiona centre sample $(D=-0.346)$, and in the Lamone sample $(D=-0.790)$. For PGI locus, no significant differences in allelic and genotypic distributions

Table 1

$\chi^{2}$-Test for differences in allelic and genotypic frequencies among sites. Tests were performed on the four Pialassa lagoons samples (Baiona south, Baiona centre, Piomboni, Baiona north) and on the overall Pialassa lagoons and Lamone estuary samples. Bonferroni adjustments were made to maintain experiment wise $P$ values of $0.05(*), 0.01(* *)$ and $0.001(* * *)$

\begin{tabular}{|c|c|c|c|c|c|c|c|c|}
\hline & \multicolumn{4}{|c|}{ Pialassa } & \multicolumn{4}{|c|}{ Pialassa and Lamone } \\
\hline & \multicolumn{2}{|c|}{ Allelic frequency } & \multicolumn{2}{|c|}{ Genotypic frequency } & \multicolumn{2}{|c|}{ Allelic frequency } & \multicolumn{2}{|c|}{ Genotypic frequency } \\
\hline & d.f. & $\chi^{2}$ & d.f. & $\chi^{2}$ & d.f. & $\chi^{2}$ & d.f. & $\chi^{2}$ \\
\hline$\overline{\mathrm{ALD}}$ & 6 & $17.01 *$ & 3 & $13.42 * *$ & 8 & $25.39 * *$ & 4 & $20.49 * * *$ \\
\hline $\mathrm{FH}$ & 3 & 4.01 & 3 & 4.07 & 4 & $25.87 * * *$ & 4 & $26.87 * * *$ \\
\hline $\mathrm{HBDH}$ & 6 & $21.38 * *$ & 3 & 8.76 & 8 & $34.65 * * *$ & 4 & $17.26^{* *}$ \\
\hline LDH & 3 & $13.22 * *$ & 3 & $11.11 *$ & 8 & $53.72 * * *$ & 4 & $12.00 * *$ \\
\hline PGI & 3 & 4.22 & 3 & 1.57 & 4 & 8.95 & 4 & 7.66 \\
\hline SDH & 6 & $25.86^{* * *}$ & 3 & 4.54 & 8 & $88.47 * * *$ & 4 & 4.69 \\
\hline
\end{tabular}

Genotype Frequency (\%) $\quad$ Allele Frequency (\%)
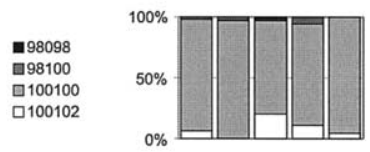

$A L D$
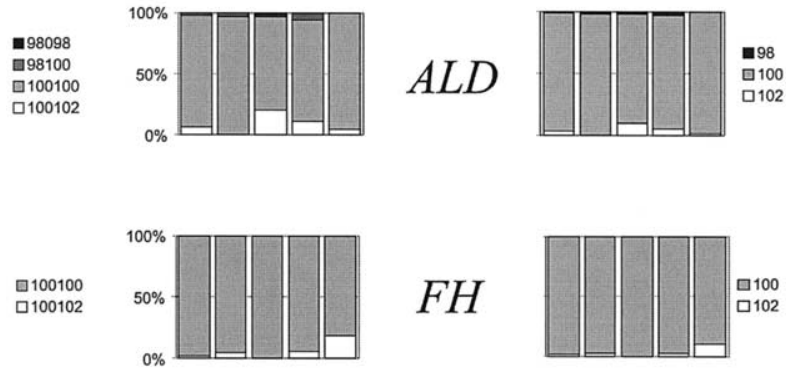

FH
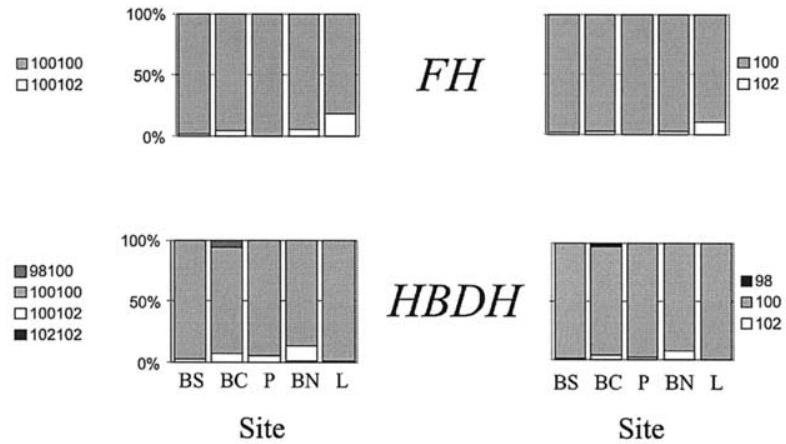

Fig. 4. Genotype and allele frequencies at loci ALD, FH and HBDH in H. diversicolor populations. Sites abbreviation as in Fig. 1.

Table 11 were observed among the Pialassa samples Fig. 5, but a significant departure from Hardy-Weinberg equilibrium was observed in the sample from the most polluted site, Baiona south Table 2, due to heterozygote deficiency $(D=$ $-0.461)$. For SDH locus, highly significant differences were detected in allelic frequencies of the Pialassa samples Table 11 with a higher abundance of 98 allele in Baiona south, the most contaminated site Fig. 5). Genotypic proportions of the Pialassa samples were not significantly different when rare genotypes were pooled Table 1). Moreover, a significant departure from Hardy-Weinberg equilibrium was observed in Baiona south Table 2 where heterozygote deficiency was observed $(D=-0.475)$.

\section{Discussion}

\subsection{Patterns of contamination of sites}

The chemical analyses of sediment cores and $H$. diversicolor tissues showed a significant spatial variability in mercury concentration in the Pialassa lagoons. Variability at the large spatial scale (sites) has been previously described (Fabbri et al., 2001a), however, small scale heterogeneity has not 
Genotype Frequency (\%)

Allele Frequency (\%)

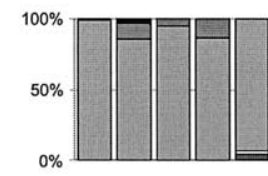

\section{$L D H$}
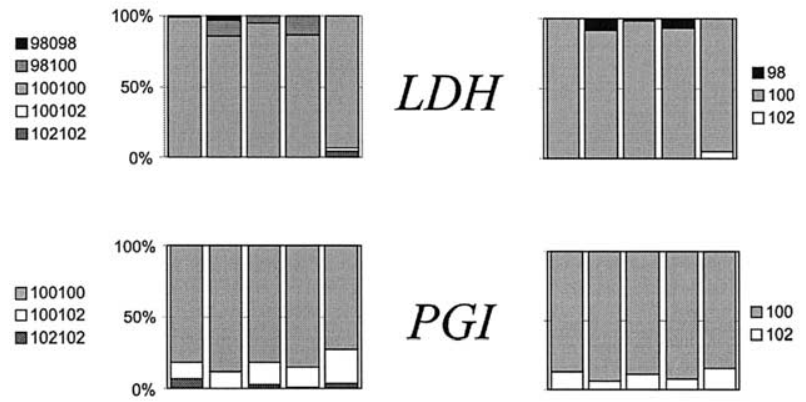

$P G I$

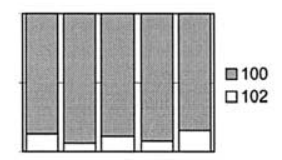

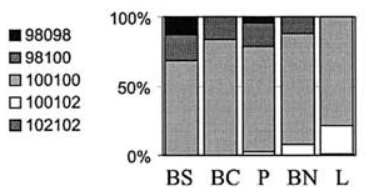

Site

\section{$S D H$}

12

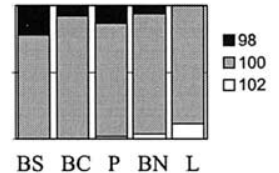

Site
Fig. 5. Genotype and allele frequencies at loci LDH, PGI and SDH in H. diversicolor populations. Sites abbreviation as in Fig. 1.

been quantified before. Possible factors that could influence the concentrations of heavy metals in sediments include chemical processes, as organic matter contents and redox conditions (Muhaya et al., 1997), physical processes, such as dredging activities, hydrodynamic mixing, resuspension of sediments (Fabbri et al., 2001a) and biological processes, such as bioturbation (Petersen et al., 1998). Small scale differences in mercury concentration values could be strongly influenced by local patterns of emersion/submersion due to semidiurnal tides. The cyclical oxidation of sediment might enhance the exchange of heavy metals between sediment particles and pore water (Volpi et al., 1999) affecting mercury distribution in sediment and bioaccumulation in $H$. diversicolor. Presence of floating agglomerates of dead macroalgae could further enhance mercury transport and redistribution across the Pialassa lagoons. Owing to the high degree of eutrophication of the Pialassa, blooms of the green algae Ulva sp. generally occur in summer (Ponti et al., in press). Ulva rigida can accumulate up to $2200 \mathrm{ng} \mathrm{g}^{-1} \mathrm{dw}$ of total mercury (Fabbri et al., 2001a). In early Autumn clots of macroalgae are transported across the lagoon by tidal flows, being a possible medium for the redistribution of contaminants. Moreover, assimilation of metals by macroalgae could affect their bioavailability for benthic deposit-feeders, con- tributing to the variability of mercury concentrations in $H$. diversicolor tissues.

Despite the high variability a trend of decreasing mercury concentration both in sediments and $H$. diversicolor tissues has been observed, Baiona south and Baiona centre being the most polluted sites, while Baiona North, Piomboni and Lamone showed low levels of contamination Figs. 2 and 3 . Differential bioavailability of the most mobile mercury fractions could provide a possible explanation for the differences in patterns of total mercury concentrations observed in sediments compared to $H$. diversicolor tissues at the two impacted sites Fig. 3). Fabbri et al. (2001a) showed that in the Pialassa Baiona proportions of the most mobile fractions of mercury (methyl mercury and mobile mercury) were higher northward from the major sources of industrial pollution, contrasting with the trend of total mercury concentration which decrease from south towards north. However, the analyses of the relative abundance of mobile mercury quantified in the two cores collected at the most contaminated sites does not confirm this trend.

Differences in mercury concentrations measured in $\mathrm{H}$. diversicolor tissues at the most polluted sites Fig. 3 could be explained by variability in bioaccumulation/detoxification rates due to adaptation/acclimation to metal pollution (Bryan and Hummerstone, 1971; Muhaya et al., 1997). Increased metal accumulation rates have been observed in $H$. diversicolor populations resistant to heavy metal pollution (Bryan and Hummerstone, 1971). Klerks and Weis (1987) suggested that resistant organisms could evolve an increased capacity to sequester the metal in a less toxic form or to have selected metabolic pathways that are less sensitive to metal concentrations (e.g. enzyme on which the metal has a critical effect could be less sensitive).

\subsection{Pattern of genetic variability in H. diversicolor}

Genetic structure of $H$. diversicolor populations from the Mediterranean coasts has been analysed by Abbiati and Maltagliati (1996). These authors found low levels of intrapopulation genetic variability and a general increase in interpopulation differentiation along a distance gradient among different brackish water basins. Genetic analyses of samples collected in the Pialassa lagoons and Lamone estuary partially confirmed these results. Genetic variability within samples was low, and a limited genetic differentiation among

Table 2

$\chi^{2}$-Test for deviation from Hardy-Weinberg equilibrium (***, $P<0.001$; **, $P<0.01$ ) in the five samples (Baiona south, Baiona centre, Piomboni, Baiona north, Lamone)

\begin{tabular}{|c|c|c|c|c|c|c|c|c|c|c|}
\hline & \multicolumn{2}{|c|}{ Baiona south } & \multicolumn{2}{|c|}{ Baiona centre } & \multicolumn{2}{|c|}{ Piomboni } & \multicolumn{2}{|c|}{ Baiona north } & \multicolumn{2}{|c|}{ Lamone } \\
\hline & d.f. & $\chi^{2}$ & d.f. & $\chi^{2}$ & d.f. & $\chi^{2}$ & d.f. & $\chi^{2}$ & d.f. & $\chi^{2}$ \\
\hline ALD & 1 & 0.155 & 1 & 0.008 & 1 & 0.000 & 1 & 0.551 & 1 & 0.054 \\
\hline $\mathrm{FH}$ & 1 & 0.007 & 1 & 0.013 & - & - & 1 & 0.029 & 1 & 0.917 \\
\hline $\mathrm{HBDH}$ & 1 & 0.006 & 1 & 0.225 & 1 & 0.041 & 1 & 1.447 & 1 & 0.000 \\
\hline $\mathrm{LDH}$ & 1 & 0.000 & 1 & $7.256^{* *}$ & 1 & 0.025 & 1 & 0.329 & 1 & $62.70 * * *$ \\
\hline PGI & 1 & $16.75^{* * * *}$ & 1 & 0.283 & 1 & 2.393 & 1 & 0.791 & 1 & 0.342 \\
\hline $\mathrm{SDH}$ & 1 & $17.81^{* * * *}$ & 1 & 0.279 & 1 & 2.621 & 1 & 0.513 & 1 & 0.080 \\
\hline
\end{tabular}


samples was observed. However, genetic structuring among samples of $H$. diversicolor was found, despite the spatial closeness of the examined samples and the apparent absence of barriers to gene flow. Six of the 19 loci examined, showed major differences in levels of polymorphism among samples. Heterozygosity, allelic and/or genotypic frequencies of loci LDH, PGI, SDH at the two most contaminated sites resulted significantly different from those measured at the less contaminated ones. PGI has shown to be affected by pollution in several species. Heagler et al. (1993) observed a decline in frequencies of the allele PGI- $2^{38}$ in field populations of Gambusia holbrooki from areas contaminated by mercury. Mulvey et al. (1995) found differential sensitivity of PGI-2 genotypes in populations of $G$. holbrooki exposed to a chronic and acute mercury stress. These authors suggest that even if allozyme polymorphism for PGI-2 is related to performance differences in stressful conditions, it is not yet possible to distinguish between differences due to the locus under study or to closely linked loci (genetic "hitchhiking"). The deviations from Hardy-Weinberg equilibria and the heterozygote deficiency observed for LDH, PGI and SDH loci at the most contaminated sites could support the hypothesis of a selective disadvantage of heterozygotes. The results of studies comparing the relative resistance of heterozygous and homozygous individuals to metal contamination do not suggest general predictable effects (see review by Roark and Brown, 1996). In the presence of stressors some species (e.g. Nectopsyche albida) show a greater resistance/survivorship of heterozygous individuals (Benton and Guttman, 1992) while in others (e.g. Gambusia affinis) homozygous genotypes at individual loci have been found to be selectively favoured (Diamond et al., 1989). Several factors could also explain the heterozygote deficiency observed in $H$. diversicolor (Wahlund effect, genetic drift, null alleles, etc.) therefore, without further experimental validations, we should be cautious in attributing a direct relationship between pollution and Hardy-Weinberg deviations for LDH, PGI and SDH loci. Loci ALD, FH and HBDH also showed non-random allelic and genotypic distributions but these variations could not be related to the gradient of contamination and do not seem to be affected specifically by pollution levels.

Allozyme loci were originally developed and widely used as neutral markers (reviewed in Belfiore and Anderson, 2001). Proponents of this idea contended that although proteins examined were known to be relevant to basic physiological functions, variants were unlikely to be selectively different. Empirical observations have led to this position being challenged by various authors (e.g. Nevo et al., 1984, 1986, 1987; Gillespie and Guttman, 1989; Roark and Brown, 1996). The present study showed the occurrence of nonrandom allozymic patterns among $H$. diversicolor samples along pollution gradient. Polymorphism at LDH, PGI and SDH loci appeared to be possibly related to the contamination levels, but observed genetic patterns do not represent evidence of a causal effect of contaminants. As Klerks and Levinton (1989) outlined, analysis of the genetic effects of pollutants in field populations is often difficult, as impacted areas may contain different toxicants, and pollutants synergism could hinder the identification of driving selective forces. Moreover the association of specific genotypes with tolerances to contaminants needs to be approached with caution (Lewis et al., 2001), as the occurrence of nongenotypic factors (e.g. environmental conditions in developmental stages, acclimation etc.) could have an important influence on tolerance. The data presented in this study provide a background necessary for experimental validation on the relationships between contamination levels and allozymic patterns of $H$. diversicolor.

\section{Acknowledgements}

J. Anderson, F. Bertozzi, A. Pasteris, M. Ponti and I. Vassura provided excellent assistance at different stages of the study. We are grateful to F. Maltagliati and the two reviewers for their valuable suggestions and criticism of the manuscript. This work was partially funded by a Murst Cofin 1999 project and by a grant from the municipality of Ravenna. This paper was written under the EU funded research contract EVK3-CT-2001-00048 (Eumar).

\section{References}

Abbiati, M., Maltagliati, F., 1996. Allozyme evidence of genetic differentiation between populations of Hediste diversicolor (Polychaeta: Nereididae) from the western Mediterranean. J. Mar. Biol. Ass. UK 76, 637-647.

Belfiore, N.M., Anderson, S.L., 2001. Effects of contaminants on genetic patterns in aquatic organisms: a review. Mutat. Res. 489, 97-122.

Benton, M.J., Guttman, S.I., 1992. Allozyme genotype and differential resistance to mercury pollution in the caddisfly, Nectopsyche albida. Part I. Single-locus genotypes. Can. J. Fish. Aquat. Sci. 49, 142-146.

Benton, M.J., Guttman, S.I., 1997. Electrophoretic evidence of esterase inhibition in larval caddisflies exposed to inorganic mercury. Water Environ. Res. 69, 240-243.

Bryan, G.W., Hummerstone, L.G., 1971. Adaptation of the polychaete Nereis diversicolor to estuarine sediments containing high concentrations of heavy metals. J. Mar. Biol. Ass. UK 51, 845-863.

Bryan, G.W., Hummerstone, L.G., 1973. Adaptation of the polychaete Hediste diversicolor to estuarine sediments containing high concentrations of zinc and cadmium. J. Mar. Biol. Ass. UK 53, 839-857.

Bryan, G.W., Langston, W.J., 1992. Bioavailability, accumulation and effects of heavy metals in sediments with special reference to United Kingdom estuaries. A review. Environ. Pollut. 76, 89-131.

Cattani, O., Fabbri, D., Salvati, M., Trombini, C., Vassura, I., 1999. Biomonitoring of mercury pollution in a wetland near Ravenna. Italy, by translocated bivalves (Mytilus galloprovincialis. Environ. Toxicol. Chem. 18, 1801-1805.

Diamond, P.M., Newman, M.C., Mulvey, M., Dixon, P.M., Martinson, D., 1989. Allozyme genotype and time to death of mosquitofish Gambusia affinis during acute exposure to inorganic mercury. Environ. Toxicol. Chem. 8, 613-622.

Fabbri, D., Felisatti, O., Lombardo, M., Trombini, C., Vassura, I., 1998. The lagoon of Ravenna (Italy): characterisation of mercury-contaminated sediments. Sci. Total Environ. 213, 121-128. 
Fabbri, D., Tartari, D., Trombini, C., 2000. Analysis of poly(vinyl chloride) and other polymers in sediments and suspended matter of a coastal lagoon by pyrolysis-gas chromatography-mass spectrometry. Anal. Chim. Acta. 413, 3-11.

Fabbri, D., Lombardo, M., Trombini, C., Vassura, I., Horvat, M., 2001a. Mercury contamination of a coastal lagoon (Pialassa Baiona, Ravenna, Italy). Mater. Geoenviron. 48, 186-192.

Fabbri, D., Gabbianelli, G., Locatelli, C., Lubrano, D., Trombini, C., Vassura, I., 2001. Distribution of mercury and other heavy metals in core sediments of the northern Adriatic sea. Water Air Soil Pollut. 129, $143-153$.

Gillespie, R.B., Guttman, S.I., 1989. Effects of contaminants on the frequencies of allozymes in populations of the central stoneroller. Environ. Toxicol. Chem. 8, 309-317.

Grant, A., Hateley, J.G., Jones, N.V., 1989. Mapping the ecological impact of heavy metals on the estuarine polychaete Nereis diversicolor using inherited metal tolerance. Mar. Pollut. Bull. 20, 235-236.

Heagler, M.G., Newman, M.C., Mulvey, M., Dixon, P.M., 1993. Allozyme genotype in mosquitofish, Gambusia holbrooki, during mercury exposure: temporal stability, concentration effects and field verification. Environ. Toxicol. Chem. 12, 385-395.

Hummel, H., Patarnello, T., 1994. Genetic effects of pollutant on marine and estuarine invertebrates. In: Beaumont, A.R. (Ed.), Genetics and Evolution of Aquatic Organisms. Chapman \& Hall, London, UK, pp. 425-434.

Klerks, P.L., Levinton, J.S., 1989. Rapid evolution of metal resistance in a benthic Oligochaete inhabiting a metal-polluted site. Biol. Bull. 176, 135-141.

Klerks, P.L., Weis, J.S., 1987. Genetic adaptation to heavy metals in aquatic organisms: a review. Environ. Pollut. 45, 173-205.

Lewis, S.S., Klerks, P.L., Leberg, P.L., 2001. Relationship between allozyme genotype and sensitivity to stressors in the western mosquitofish Gambusia affinis detected for elevated temperature but not mercury. Aquat. Toxicol. 52, 205-216.

Long, E.R., MacDonald, D.D., Smith, S.L., Calder, F.D., 1995. Incidence of adverse biological effects within ranges of chemical concentrations in marine and estuarine sediments. Environ. Manage 19, 81-97.

Muhaya, B.B.M., Leermarkers, M., Baeyens, W., 1997. Total mercury and methylmercury in sediments and in the polychaete Nereis diversicolor at Groot Buitenschoor (Sceldt estuary, Belgium). Water Air Soil Pollut. 94, 109-123.

Mulvey, M., Newman, M.C., Chazal, A., Keklak, M.M., Heagler, M.G., Hales, L.S., 1995. Genetic and demographic responses of mosquitofish (Gambusia holbrooki Girard 1859) populations stressed by mercury. Environ. Toxicol. Chem. 14, 1411-1418.

Nei, M., 1978. Estimation of average heterozygosity and genetic distance from a small number of individuals. Genetics 89, 583-590.
Nevo, E., Ben-Shlomo, R., Lavie, B., 1984. Mercury selection of allozymes in marine organisms: prediction and verification in nature. Proc. Natl. Acad. Sci. USA 81, 1258-1259.

Nevo, E., Lavie, B., Noy, R., 1987. Mercury selection of allozymes in marine gastropods: prediction and verification in nature revisited. Environ. Monit. Assess. 9, 233-238.

Nevo, E., Noy, R., Lavie, B., Beiles, A., Muchtar, S., 1986. Genetic diversity and resistance to marine pollution. Biol. J. Linn. Soc. 29, 139-144.

Pasteur, N., Pasteur, G., Bonhomme, J., Catalan, J., Britton-Davidian, J., 1988. Practical isozyme genetics. Ellis Horwood, Chichester.

Patarnello, T., Guinez, R., Battaglia, B., 1991. Effects of pollution on heterozygosity in the barnacle Balanus amphitrite (Cirripedia: Thoracica. Mar. Ecol. Prog. Ser. 70, 237-243.

Petersen, K., Kristensen, E., Bjerregaard, P., 1998. Influence of bioturbating animals on flux of cadmium into estuarine sediment. Mar. Environ. Res. 45, 403-415.

Ponti M., Giaquinta S., Abbiati M 2003. Pialassa Baiona Lagoon, Ravenna, northern Adriatic sea. LOICZ Reports and Studies LOICZ, Texel, The Netherlands.

Roark, S., Brown, K., 1996. Effects of metal contamination from mine tailings on allozyme distributions of populations of great plains fishes. Environ. Toxicol. Chem. 15, 921-927.

Saiz-Salinas, J.I., Francés-Zubillaga, G., 1997. Nereis diversicolor: an unreliable biomonitor of metal contamination in the 'Ria de Bilbao' (Spain). PSZNI. Mar. Ecol. 18, 113-125.

Schneppenheim, R., Mac Donald, D.C.M., 1984. Genetic variation and population structure of krill (Euphausia superba) in the Atlantic sector of Antarctic waters and off the Antarctic peninsula. Polar. Biol. 3, 19-28.

Swofford, D.L., Selander, R.B., 1981. Biosys-1: a Fortran program for the comprehensive analysis of the electrophoretic data in population genetics and systematics. J. Hered. 72, 281-283.

Troncoso, L., Galleguillos, R., Larrain, A., 2000. Effects of copper on the fitness of the Chilean scallop Argopecten purpuratus (Mollusca: Bivalvia. Hydrobiologia 420, 185-189.

Volpi, G.A., Cavallini, L., Delaney, E., Tagliapietra, D., Ghetti, P.F., Bettiol, C., Argese, E., 1999. H. diversicolor, N. succinea and P. cultrifera (Polychaeta: Nereididae) as bioaccumulators of cadmium and zinc from sediments: preliminary results in the venetian lagoon (Italy). Toxicol. Environ. Chem. 71, 457-474.

Wallschlager, D., Desai, M.V.M., Spengler, M., Wilken, R.D., 1998. Mercury speciation in floodplain soils and sediments along a contaminated river transect. J. Environ. Qual. 27, 1034-1044.

Woodward, L.A., Mulvey, M., Newman, M.C., 1996. Mercury contamination and population-level responses in chironomids: can allozyme polymorphism indicate exposure? Environ. Toxicol. Chem. 15, 1309-1316. 